NORDISK MUSEOLOGI 1993 • 2

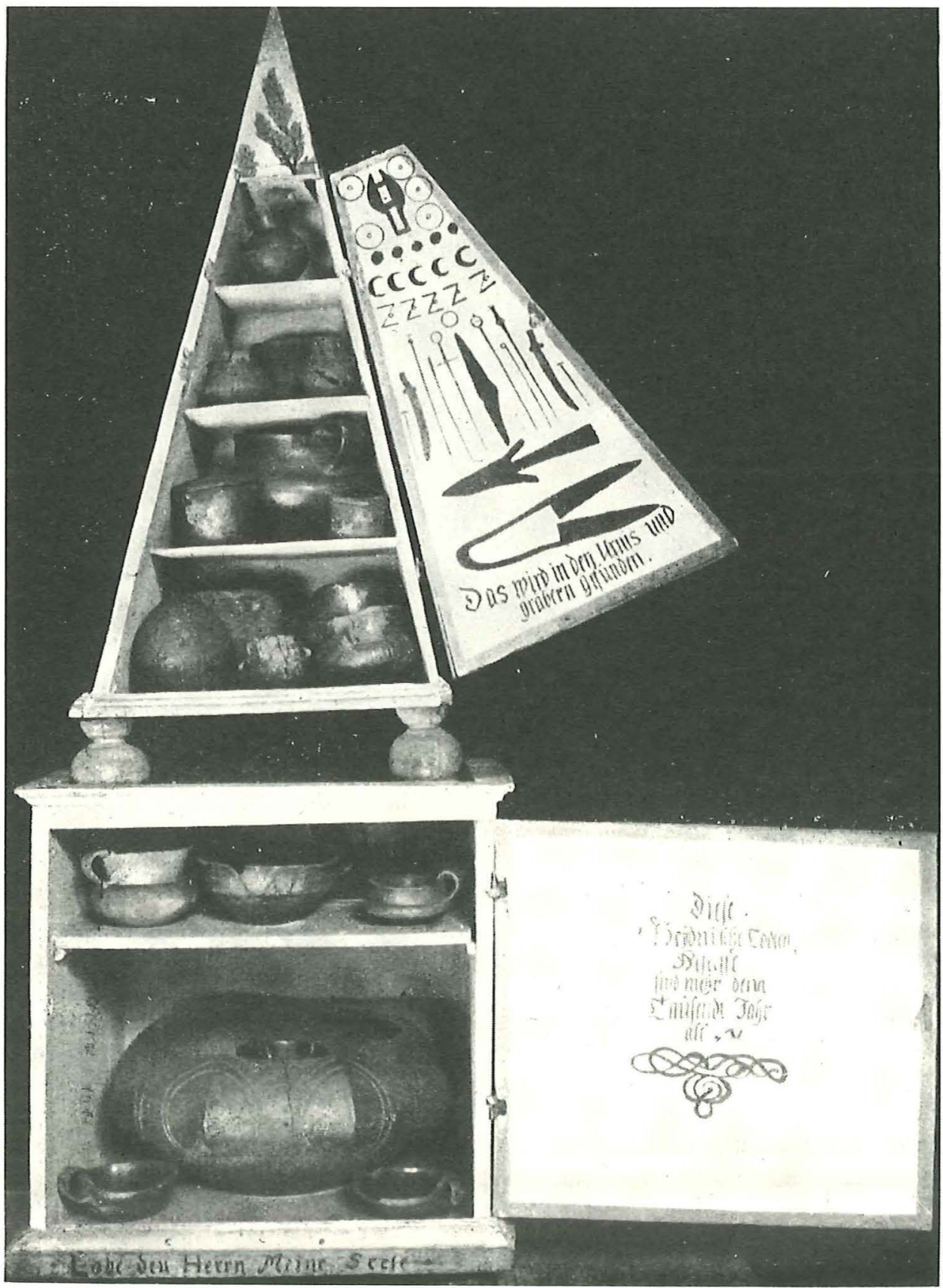

Fig. 1. L.D. Hermann's pyramidal cabinet opened, showing his collection of Silesian urns. After Stemmermann 1934. 


\section{ANTIQUARIAN ATTITUdeS CHANGING RESPONSES TO THE PAST IN THE MUSEUM ENVIRONMENT}

\section{Arthur MacGregor}

Of the many attributes that may deem an object worthy of inclusion in a museum, that of antiquity is one of the most potent - in a sense the most powerful of all, for other considerations such as beauty of form, originality of design, quality of workmanship or historical association may all be glossed over in the presence of extreme age. While antiquities have formed common components of museums throughout the history of collecting, striking changes have taken place in the significance attributed to them, not merely in the light of better understanding but more fundamentally in the way in which perceptions of antiquity itself have been repeatedly revised and reinterpreted within the museum context. These twin considerations of expanding understanding and changing perceptions of the past within the museum programme will form the basis of my paper.

\section{AMBIGUITY \\ AND THE KUNSTKAMMER}

In the Renaissance Kunstkammer, antiquities occupied a place that was - like so many other categories of material - less clearly segregated than would be conceivable today. The integrity of the collection, rather than the special significance of its constituent parts, was of prime importance: the museum was essentially a work of compilation, easily understood and frequently referred to in the same terms as a work of literary anthology.' Again, the language of grammar presents itself today as the most apposite means of comprehending significance within Renaissance collections: the concepts of synecdoche - pars pro toto - and metaphor encapsulate perfectly the manner in which the fragment might substitute for the whole in a symbolic rather than a purely physical sense, or in which, for example, the heavenly planets might be represented by an armillary sphere. The element of ambiguity which such multiple interpretations 
8 encouraged was to prove of real significance in allowing antiquities to be absorbed into the collection even at a time when their precise identity remained little understood.

It was, of course, the more formal monuments of classical Rome that were to provide collectors with the most direct opportunity of confronting the past, but just at the time when material remains of the Roman world were becoming more familiar, artefacts from the infinitely more obscure prehistoric societies of northern Europe also began to infiltrate the museum. Inevitably, comprehension of their significance was very limited at first: there was simply no conceptual framework within which such items could be fitted, nor any idea of a time-scale within which they might belong. In England the debate into the age of the earth itself seemed to have been settled for good with publication of the findings of a learned Irish divine, Archbishop James Ussher (1581-1656), that the very year of the Creation had been fixed at $4004 \mathrm{BC}^{2}$ Even within this limited time-scale for mankind - which shared, in Sir Thomas Browne's words, 'the same horoscope as the world' there seems to have been a reluctance to speculate on the condition of such inhabitants as northern Europe may have had before its encounter with Roman civilization. Indeed, opinion seems to have been that they were in general so benighted as to be best ignored.

Given these unpromising circumstances, the ensuing difficulties of interpretation of archaeological material become entirely understandable. To take the example of pottery vessels which were discovered from time to time containing prehistoric burials, there was an extended period of uncertainty during which their very status as man-made objects was hotly contested. As early as 1416 certain tracts of ground were investigated at the instigation of an Austrian duke, Ernst der Eiserne, in response to rumours that pots in various shapes had sprung naturally from the earth there; some of these pots were conveyed to the duke himself, and although his response is not recorded, for many years opinion as to their origin continued to favour spontaneous production rather than human agency. ${ }^{3}$ Typical of the light in which they were regarded is the account published in 1562 by a Lutheran pastor named Mathesius:

It is indeed remarkable that these vessels are so varied in shape that no one is like the other, and that in the earth they are as soft as coral in water, hardening only in the air... It is said that there was once a grave on the spot, with the ashes of the dead, as in an ancient urn... But since the vessels are only dug up in May, when they reveal their position by forming mounds as though the earth were pregnant (which guides those who seek them) I consider them to be natural growths, not manufactured, but created by God and Nature. ${ }^{4}$

A similar belief in these 'gewachsene Töpffe' is reported a few years later by Petrus Albinus, confirming that others believed the pots to be deeply buried in winter time, rising close to the surface and hence being recoverable only in the summer months. ${ }^{5}$ Such a view remained prevalent for many years to come,${ }^{6}$ although the fact that some pots came to be preserved in museum collections provided opportunities for more objective assessments to be made. Rudolf II was intrigued by the 
nature of archaeological items from his territories in Lusatia and Silesia and valued them for his cabinet, for more than once orders were issued to provincial governors for any vessels discovered in the ground to be sent to enrich the imperial collections in Prague; in 1577 he even initiated excavations at Gryzyce with the purpose of expanding his collections and is said to have taken a hand in lifting the urns himself.' That enlightened collector Augustus of Saxony correctly identified some urns which had been sent to him and placed them in his Kunstkammer at Dresden as early as 1578 .

While vessels of Roman and later of Greek origin came to be collected specifically as representatives of the civilisations that produced them, much of the appeal of these early pieces clearly lay not in the realm of antiquarianism but in the very uncertainty surrounding their origins, a feature that increased their desirability rather than compromising it.

A similar ambiguity - a quality on which much positive value was placed in the Baroque period - surrounded a second category of antiquities in whose identification Ole Worm was involved, although not in this instance to useful effect. Some local finds of stone implements, in which Denmark is pre-eminently rich, found their way into Worm's museum and despite the objective reasoning he applied to them as to all the material he studied, they evidently presented insurmountable difficulties of interpretation. His discourse on these items identifies them by the name of 'ceraunia', coined because they were thought to originate in flashes of lightning: ${ }^{8}$

They have various shapes, sometimes conical, sometimes hammer- or axe-shaped, and with a hole in the middle. Their origin is disputed; some deny they are meteorites, supposing from their resemblance to iron tools that they are really such tools transformed into stones. On the other hand, reliable witnesses state that they have observed these stones on the precise spot ... where lightning had struck... 9

Two generations earlier, Michele Mercati, curator of the Vatican collections, had established at least elements of the truth in his Metallotheca, written in 1574, but since this important work remained unpublished until 1719, it failed to make the impact it deserved. ${ }^{10}$ Hence in 1737 the inventory of the Royal Danish Kunst kammer (which absorbed Worm's collection) still listed among the contents of the 'Chamber of Natural Productions' (rather than the neighbouring 'Chamber of Antiquities') 'Twenty-three stone knives or small ceraunia', 'eleven cerauniae of various sizes, with holes', and 'Nine larger ... without holes' - all seemingly acknowledging the possibility of human production but ultimately consigned with the fossils, 'eagle stones', and flints shaped like birds' beaks or human ears. ${ }^{11}$

Nor was Denmark noticeably backward in this respect. The catalogue of the 'Repository' of the Royal Society in London, published in 1681, likewise equated flint arrowheads and blades with natural crystals and other 'regular stones' in the collection, and while certain antiquaries such as Sir William Dugdale and Robert Plot were already clear in their identification of stone axes as man-made objects, Sir Hans Sloane, whose collection was to form the foundation of the British Museum at his death in 1753, alludes to the survival of some doubt well into the 
10 eighteenth century: thus in his own catalogue he could add to his confident description of 'An ancient gray stone hatchet [with] notches to be fixed to its handle' the information that such items were yet 'called by some thunder stones', and could record elsewhere 'An Irish hatchet made of green spleen stone found after a shoure \& thunder by a ditcher who thought it hott'. ${ }^{12}$ Ultimately it was the accumulation in various museums of ethnographic material from the New World that provided incontrovertible evidence: Plot, the first keeper of the Ashmolean Museum at Oxford, supported his identification of stone axes with the statement that how they may be fastened to a helve, may be seen in the Musaeum Ashmoleanum where are several Indian ones of the like kind', ${ }^{13}$ while his deputy, Edward Lhwyd, similarly disposed of the 'elf arrows' he had encountered in the Scottish highlands by demonstrating that 'they are just the same chip'd flints the Natives of New England head their Arrows with at this Day', adding that 'there are also several Stone Hatchets found in this Kingdom, not unlike those of the Americans' ${ }^{14}$ Shortly afterwards we find the same sort of comparisons being made by Kilian Stobaeus, professor of natural history at the University of Lund, when, in 1738, he published an article asserting the manmade origins of flint tools and drawing his proofs from comparisons with American flints in the Royal Kunstkammer at Copenhagen. ${ }^{15}$ At this point the museum collections which had provided safe repositories for material which at the time of discovery was little understood began to perform one of the prime functions which they continue to provide today, in allo- wing new understanding to emerge from detailed comparisons of constituent elements of the existing collections. A similar fate overtook other material in these collections during the seventeenth century, when exhibits such as unicorn horns came to be related to marine mammals rather than mythical quadrupeds (a process in which Worm again had a hand), and petrified 'serpents' tongues' or 'glossopetrae' lost their amuletic appeal when they were accurately identified as fossilized teeth of shark-like fish. What seems curious from our perspective is that the true nature of such items took so long to achieve general recognition after the correct identification had first been made: to some degree the role of the museum as a recreational device, designed to encourage speculation rather than to provide answers for precisely framed questions, must have actively prolonged the retention of alternative interpretations in the face of the pedantic pursuit of truth.

\section{ANTIQUITY BEFORE AND DURING THE ENLIGHTENMENT}

Roman antiquities formed absolutely standard components of museums throughout the earlier phases of collecting. It is easy for us tacitly to assume that such material must necessarily have been desirable and hence in some sense inherently collectable, but while some pieces did find an appreciative audience during the medieval period, a striking reminder of the contempt in which (pagan) Roman material could be held at that time is provided by the marble Venus Victrix found in the cemetery of St. Matthias at Trier and set up so that pilgrims could gain added 
merit by throwing stones at it. ${ }^{16}$ In the more enlightened milieu of the Renaissance collector, funerary and other inscriptions as well as sculpture proved open to easy interpretation by those with a modicum of learning; military monuments - particularly prolific in northern Europe - gained a dramatic impulse from the insights provided by Tacitus' Germania, the text of which was discovered in 1455 and published in Nürn-berg in 1473. Coins proved even more useful and valuable, supplying literary, historical and personal emblems to complement whatever degree of classical scholarship the collector might have acquired.

In princely circles, these commodities took on an added meaning. The Habsburg princes and their neighbours, for example, took a particular interest in the dynastic interrelationships of their imperial forefathers (as they saw them) and took a special delight in representations of the Roman emperors, whether as busts or fulllength statues, as coins or as the medallions and plaquettes which came to be manufactured specifically for the collector's market. Maximilian I of Austria (d. 1519) forms an early example of a collector who developed a special interest in Roman coins and inscriptions, stemming from his genealogical preoccupations, ${ }^{17}$ and although Maximilian himself never promoted excavations, he took care to have finds sent from all corners of his empire. $^{18}$

Albrecht V of Bavaria (1500-79) developed the concept of the collection as an instrument of dynastic legitimation to its ultimate form in his Antiquarium at Munich. In this purpose-built vaulted chamber in the ducal residence, some 200 busts of Antique and other rulers, many of them clumsy fakes or copies but all firmly labelled with their pretended identities, fulfilled their allotted role of demonstrating the lineage from which the duke drew his hereditary authority and his personal virtus. ${ }^{19}$ Authenticity of the individual pieces was clearly of secondary interest in this highly symbolic context where the individual image could contribute its meaning irrespective of - or rather in spite of - what might have been a questionable pedigree.

Under this heightened level of antiquarian consciousness certain classes of antiquities, at least, enjoyed increasing appreciation from a wider social spectrum. We hear, for example, of a collection of Roman inscriptions from Salzburg built up by 1520 by Johannes Thurnmayer-Aventinus and of a similar collection later formed by Hieronymous Beck of Leopoldsdorf, installed as a lapidarium at Schloss Ebreichsdorf near Vienna. ${ }^{20}$

At the same time as the Austrians began to take an antiquarian interest in sites such as Carnuntum on the Danube, the remains of the Roman settlement at Augst near Basel were receiving attention from the Swiss collector Basilius Amerbach (d. 1591): a ground-plan and several views of the theatre there, executed on his behalf, still survive in the university library at Basel, while such finds as were made were absorbed into his cabinet of several thousand items of all sorts - a collection, incidentally, which was bought after his death by the city council and placed on publicly-accessible display at the university in $1661 .^{21}$

Throughout the period under review, coins and medals enjoyed a much wider popularity than other classes of antiquities 
12 as collectable items, yet the history of coin collecting remains to be written. Their appeal was almost universal, fulfilling at once the needs of the impecunious collector of modest ambition and the princely virtuoso whose collection might fill many cabinets with valuable pieces and which might even merit the attentions of a scholarly curator. When John Ray visited the Elector Karl Ludwig's collection in Heidelberg in 1663, for example, he found there 'an excellent collection of ancient and modern coins and medals in which the Prince himself is very knowing'. Karl Ludwig's librarian, Lorenz Beger, was placed in charge of the collection and in 1685 produced an account of it entitled Thesaurus Palatinus. In the following year he accompanied the collection to Berlin when it was inherited by Friedrich Wilhelm, Elector of Brandenburg (1620-88) and in 1693 gained overall charge of the electoral collections. ${ }^{22}$

As well as coins and medals (numbering over 22,000 by the end of the seventeenth century) the Brandenburg Antiquitätenkammer was well endowed with antiquities, some of which are of particular interest since they represent the fruits of deliberate archaeological investigations in the province of Kleve in the lower Rheinland, the property of Brandenburg since $1614:^{23}$ many of these were added by Christian von Heimbach, appointed official Antiquarius by the Elector in 1663, who apparently carried out excavations in Kleve thereafter in order to augment the collection. ${ }^{24}$ Other elements were acquired by purchase, as when the Elector bought the entire collections of his minister Erasmus Seidel in 1642 and of Hans Ewich of Xanten in $1680 . .^{25}$ On the evidence of Ewich, we know in addition that large numbers of Roman lamps and vessels were sent to the Elector from Xanten, some of them drawn by Ewich himself. Lamps such as these formed ideal collectors' pieces, being attractive and portable, and in their iconography providing the basis for much philosophical speculation. ${ }^{26}$

Local antiquities also began to be treasured and collected more widely, although at this period such ventures were still unusual. The extensive urnfields of northern Central Europe were particularly productive: from the early years of the eighteenth century, for example, Leonhard David Hermann in Poland had displayed his collection of Silesian urns and other antiquities in a specially designed cabinet labelled Mausoleum but described elsewhere with more appropriateness as a shrine. ${ }^{27}$ Such a cabinet - either the same one with its decoration modified since Hermann described it or a closely similar one which had also been made for him - was published in the 1930s by Stemmermann (see Figs. 1-2), together with a detailed analysis of its painted iconography. ${ }^{28}$ This cabinet (which was then in the Breslau museum) must undoubtedly be counted as one of the most important museological monuments of its age.

In Poland the interest of King Stanislaw Augustus (1764-95) in antiquities led him and in turn his courtiers to carry out excavations and as early as 1786 plans were drawn up for a systematic programme of excavations and for the founding of a national museum to house them, but nothing came of it. ${ }^{29}$ Neither was there by any means a universal appreciation of the antiquarian value of excavated material: Karel Sklená tells us of a Furstenberg prince, for example, on whose estate in Bohemia a 


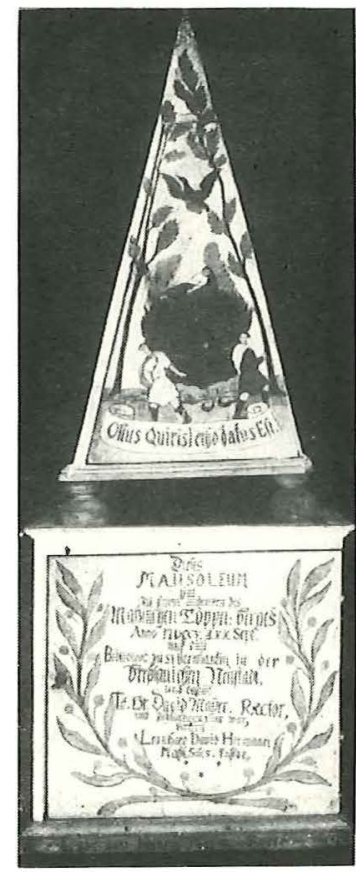

a.

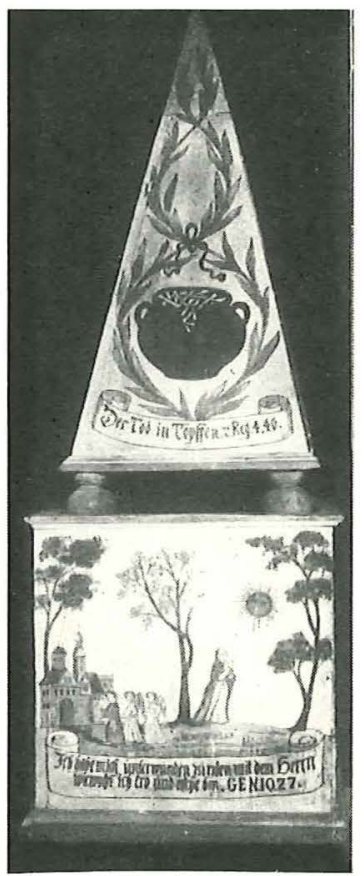

b.

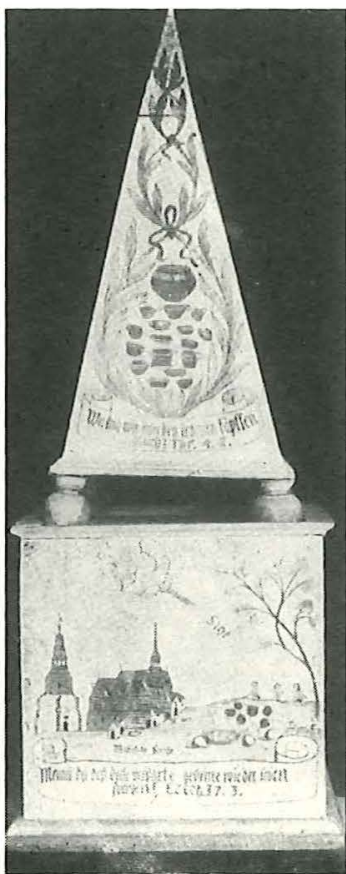

c.

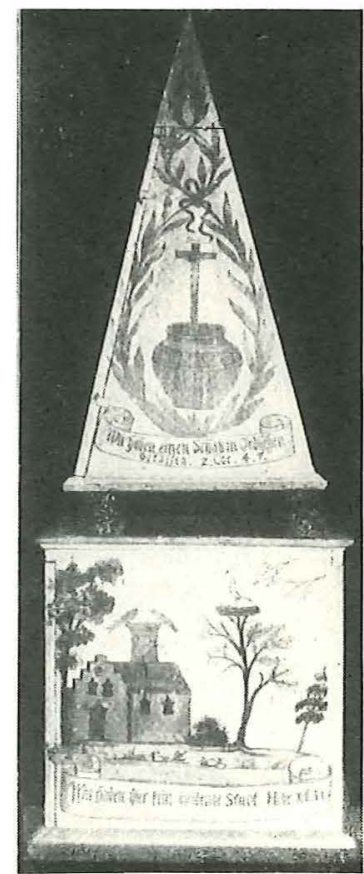

d.

Fig. 2. L.D. Hermann's pyramidal cabinet: $a$, front; $b$, right side; $c$, back. d, left side. After Stemmermann 1934.

huge hoard of several thousand Celtic gold coins was found in 1771, and who, despite holding office as the first chairman of the national scientific society of his country, had nearly all of them melted down and reminted with his own portrait on them. ${ }^{30}$

By now the earliest attempts at classification and comparison between different collections were being made, but as yet the establishment of any sort of chronology remained beyond the grasp of researchers. Up to this point the collectors had all their own way, no thought being spared for any wider significance that artefacts might have as elements in a system of evidence incorporating the parent monument itself. By the early eighteenth century, however, we find A.A. Rhode in Germany castigating those who destroyed whole barrows down to their foundations, 'grubbing like swine' for collectable items, ${ }^{31}$ and a generation later in England James Douglas (1753-1819), excavator, preserver and careful publisher of extensive cemeteries of the Anglo-Saxon period in Kent, deplored those who 'hoard up antique relics as children collect gegaws' ['toys']: 'These philistines', he suggested, 'often expose the more reflecting antiquary whose only view in collecting [antiquities] is to throw light upon history or place some doubtful custom of an antient people in a more accurate point of light, to the pleasantry of his friends, and the ridicule of the unlettered part of the world'. ${ }^{32}$

In Scandinavia, meanwhile, a chapter in this history was about to unfold in which museum collections were to make their single most important contribution to the advance of archaeological theory. On 22 May 1807 the Crown Prince of Denmark signed the instruments establishing a new national museum of antiquities. Among its declared aims were that it should '...house all the archaeological objects to be found within His Majesty's domains, 
14 in so far as they already form part of the Royal collections or in the course of time might be incorporated into them...', and further that 'It must then be considered how this museum could then be run for the benefit of the general public. ${ }^{33}$

The decision to found a state museum of antiquities, an important development in its own right, was rendered that much more valuable by the appointment of Christian Jürgensen Thomsen as its (unpaid) secretary. Within a year of his appointment to the post, Thomsen had not only catalogued a large part of the collection with meticulous care, but had laid the foundations of a system of categorization that was not only to serve the museum well but which was to form the basis of a comprehensive framework applicable to prehistoric societies in the broadest sense. The 'Three Age' system which Thomsen evolved has been called 'the first paradigm in archaeology', and its importance in the history of the subject can hardly be overstated..$^{34}$ Although he makes no special reference to it, the three principal phases of Thomsen's system, which he defines partly on material and partly on technological criteria, represent in effect an historical sequence which was to form the accepted basis not only for the display of the past but for its archaeological interpretation for generations to come. What is perhaps more remarkable is that he elucidated it on the basis of observed characteristics, without the benefit of previouslypublished comparative data and without assistance from stratigraphic sequences of objects owing to the lack of recorded information and to the fact that the bulk of his collection was made of stray finds. The prime requirement of this new scien- ce was, in his own words, 'a pair of sharp eyes'. In 1836 these ideas, which had been taking form in his mind for over a decade, were published in a Guide Book for Northern Antiquity, in which the field monuments of Denmark were also related to the artefacts in the collection. ${ }^{35}$

\section{ANTIQUITY, NATIONALISM AND THE ROMANTIC PERIOD}

By this time, important developments had taken place which both expanded the number of antiquarian museums and enlarged the influence they were to have on society at large. Throughout the European continent a potent influence was at work in the form of the Romantic movement which promoted many of the heroic concepts around which national ideals were to crystallize. In Scandinavia, for example, where the sagas provided a ready-made reservoir on which the Romantics drew heavily for inspiration, field monuments, runic slabs and other antiquities were mobilized to the same ends, with the result that museums regained something of their original status as 'temples of the muses', though now acknowledging a Nordic rather than a classical pantheon.

They were also drawn into contemporary politics in a manner not experienced before or since. Thomsen, whose crucial work in the Copenhagen museum has already been mentioned, attracted considerable criticism when in the 1830 s he encouraged the setting up of a museum at Kiel in Schleswig-Holstein, at that time still attached to the Danish crown. ${ }^{36}$ Many of Thomsen's compatriots were bitterly opposed to his plan to send part of the 
Copenhagen collection - their national patrimony - to Kiel while many Germans saw the move as merely another instance of Danish cultural imperialism. The Three Age system, although it had already begun to find adherents in Germany even before Thomsen published his influential work, became identified in some eyes specifically with Nordic influence and certain German workers who accepted its precepts too readily found themselves vilified by their more militantly nationalist colleagues. Thomsen's motives with respect to the Schleswig museum were completely altruistic, however: 'we may lose ten pieces a year', he wrote to a colleague, 'but on the other hand a hundred will be saved to scholarship which would previously have been unknown to us'. Thomsen's successor, J.J.A. Worsaae, another of the really great figures in the history of Scandinavian archaeology, was even more consciously influenced by the Romantic movement: 'The remains of antiquity', he wrote, 'bind us more firmly to our native land'. He continued:

they constantly recall to our recollection, that our forefathers lived in this country, from time immemorial, a free and independent people, and so call on us to defend our territories with energy, that no foreigner may ever rule over that soil, which contains the bones of our ancestors, and with which our most sacred and reverential recollections are associated'. ${ }^{37}$

Elsewhere he expanded on this theme: 'A nation which respects itself and its independence cannot possibly rest satisfied with the consideration of its present situation alone. It must of necessity direct its attention to bygone times ... so as to ascertain by what means it has arrived at its present character and condition. ${ }^{38}$

In Germany a growing feeling of identity with the concept of Fatherland was given full expression following the defeat of Napoleon and withdrawal of the occupying French forces. In many of the small states that characterized then the German republic of today, so-called vaterländische Museen were founded with specific programmes aimed at establishing the special characteristics of each princedom in terms of its history and archaeology as well as its natural resources. An unprecedented identity of purpose grew up between the aims of the state and the interests of the antiquaries, who frequently found themselves housed in purpose-built premises that proclaimed the importance attached to their functions.

What was perhaps more important was that the interest they represented was now distributed on a wide social spectrum in which the influential middle classes were particularly prominent. It was they who fuelled the literary and artistic dimensions of the Romantic movement whose interrelationships with historical themes meant that topics of antiquarian interest were among the common currency of the genre. The social impact of archaeology has never been more dramatically direct. Under the impetus of influential figures such as Goethe, who was among the sponsors of the first archaeological and historical society in Germany, founded in Bonn in 1814 , so enthusiastically was the movement taken up 'to nurture love for our common Fatherland and for the memory of our great forbears' that by the early 1850 s virtually every major town had one. In a way there was a price to pay for this 
16 duplication of effort in so many centres, because it was not until the middle of the century that the founding of a United Society of German Historical and Antiquarian Societies led to the establishment of museums encompassing the national aspirations of all of these peoples in the form of the Germanisches National museum in Nürnberg and the RömischGermanisches Museum in Mainz. ${ }^{39}$

Just as museums and the study of the past in general could perform a valuable political role in this way, in the wrong hands (in the state's view, that is) they could be seen as powerful and even dangerous centres for subversive influence. This was particularly the case in the easternmost provinces of the Habsburg empire where Magyar nationalism led to the foundation in Budapest of the National Museum in 1811, very much in the teeth of opposition from the central authorities in Vienna. Elsewhere in Hungary a Museum was founded at Martin in 1863 to serve a similar purpose for the Slovak community but its aims ran contrary to the Hungarian government's plans for the Magyarization of Slovakia and they had it shut down within twelve years as a potentially dangerous institution. Even within Austria itself there was official alarm at the potential threat to the integrity of the empire represented by the German nationalist movement

And finally I should mention the establishment in Prague of the Czech National Museum, whose sponsors were the very same personalities who led the movement that established the character and course of Czech nationalism. Though originally biased in the direction of natural sciences, archaeology played an increasingly important role here and formed an independent department from the 1840 s. By 1843 J.E. Vocel had formulated his concept of a 'Czech national archaeology'. ${ }^{40}$

It is not inappropriate to bring this very incomplete survey to a close at this point. The Habsburgs, more than any other noble family had been responsible for the introduction of the museum as a concept into Europe north of the Alps; here in Prague in 1818, the spiritual successor to the Austrian Imperial cabinet achieved an independence that symbolized not only the political unchaining of the Slavs but also the freeing of the museum to shoulder the tasks we still expect of it today, not only to preserve the past but to foster understanding of it and above all to make it relevant.

A primary aim of 'Museum Europa', as declared in its prospectus, has been to demonstrate how 'Europe as an idea and concept was conceived and ... developed parallel to the Museum'. The point is well worth making, for a necessary prerequisite for the evolution of a common identity was undoubtedly the establishment by the member states of their individual identities, both cultural and political; few institutions have played so valuable a role in this process as the museum, which not only held up to the public the mirror of their own past but which invented the very language by which it could be comprehended.

Arthur MacGregor leder Department of Antiquities vid Ashmolean Museum, Oxford. Han är en av redaktörerna av Journal of the History of Collections, som började utges av Oxford University Press 1989.

Adr: 30 Sutherland Avenue, Maida Vale, London W9 2HQ, England. 


\section{NOTES AND REFERENCES}

1. It is now well recognized that the term 'museum' comprehended a variety of constructs of which the idea of a literary compilation of factual matter was at least as widely understood as that of a physical collection of objects: see Paula Findlen, 'The museum: its classical etymology and Renaissance genealogy', Journal of the History of Collections 1 no. 1 (1989), pp. 59-78.

2. So widespread was acceptance of this date that it was added as a marginal gloss to a new edition of the Authorized Version of the Bible published in England in 1701.

3 P.H. Stemmermann, Die Anfange der deutschen Vorgeschichtsforschung (Quakenbrück i Hann, 1934), pp. 678; K. Jazdzewski, Poland (London, 1965), p. 13; L. Franz, 'Aus der Geschichte der Ur- und Frühgeschichtlichen Bodenforschung in Österreich', in L. Franz and A.R. Neumann (eds.), Lexikon ur-und frühgeschichtlicher Fundstätten Österreichs (Vienna, 1965), p. 211. All of the above quote the Historia Poloniae of Jan Dlugosz, Archbishop of Lemberg (1415-18).

4. The earliest edition of this work that I have been able to consult is that of 1571 , entitled Sarepta, darinn von allerley Bergwerck ... (Nürnberg); see particularly Predigt. XV. The passage quoted in translation here is from Karel Sklenár, Archaeology in Central Europe. The first 500 years (Leicester, 1983), p. 36.

5. Petrus Albinus, Meissnischen Land- und Berg-Chronika (Dresden, 1589-90), part II, p. 178. Albinus mentions a widespread belief among the peasants that these pots were freshly made by dwarfs, who abandoned them underground.

6. Although their true nature was first published in the sixteenth century, for example by Agricola in his De natura fossilium of 1546, final acceptance of their man-made status was not to come for another 300 years: H.J. Eggers (Einfiuhrung in die Vorgeschichte (Munich, 1959), pp. 25-6) mentions that urns were last published as natural phenomena as late as 1816 .

7. H. Kühn, Die Geschichte der Vorgeschichtsforschung (Berlin, 1976), p. 18. Stemmermann (1934), p. 69) records that Rudolf had a wooden column erected on the spot to commemorate the occasion - 'Das erste Denkmal für
Altertumsfunde'.

8. Greek: a thunderbolt. The identification of stone axes as 'thunderstones' was evidently of some antiquity: Eggers (1959, p. 25) mentions that throughout the medieval period they had been esteemed as a protection against lightning and were, on occasion, mounted as amulets; the Emperor Henry IV received one as a gift in 1081, mounted in gold. In the mid-nineteenth century there were still some in Ireland who clung to the 'vulgar opinion' that stone axes were formed in thunderbolts: see Descriptive Catalogue of the Collection of Antiquities ... illustrative of Irish History, exhibited at the Museum, Belfast, on the occasion of the twenty-second meeting of the BAAS, September 1852 (Belfast, 1852), appendix.

9. O. Klindt-Jensen, $A$ History of Scandinavian Archaeology (London, 1975), p. 23.

10. See Michelis Mercati samminiatensis Metallotheca (Rome, 1719), p. 243.

11. B. Gundestrup, Det kongelige danske Kunstkammer 1737 / The Royal Danish Kunstkammer 1737 (Copenhagen, 1991), vol. I, pp. 136-8.

12. See A. MacGregor, 'Prehistoric and Romano-British antiquities', in Sir Hans Sloane ... Founding Father of the British Museum, ed. A. MacGregor (forthcoming).

13. Robert Plot, The Natural History of Stafford-shire (Oxford, 1686), p. 396.

14. See J.L. Campbell and Derick Thomson, Edward Lhuyd in the Scottish Highlands 1699-1700 (Oxford, 1963), p. 99.

15. K. Stobaeus, 'Ceravnii beyuliqve lapides dissertatione historica' (1738), Opera in quibus petrefactorum numismat. et ant. hist. (Dantisci, 1753), quoted in Klindt-Jensen 1975, pp. 38-9.

16. Kühn 1976, p. 15; K. Böhner, 'Altertumssammlungen Gestern und Heute', Jahrbuch der Römisch-Germanischen Zentralmuseums Mainz 17 (1970), p. 12.

17. M.A. Niegle, Die archäologische Evforschung der Römerzeit in Österreich (Österreichische Akademie der Wissenschaften, Phil.-Hist. Klasse, Denkschriften 141) (Vienna, 1980), pp. 30-1.

18. In 1508 , for example, he had items brought from as far away as the Roman fort at Roomburg near Leiden to enrich his collection: see Sklenár 1983, p. 28.

19. H. Frosien-Leinz, 'Das Antiquarium der Residenz: erstes 
Antikenmuseum Münchens', in Glyptothek München 18301980, ed. K. Vierneisel and G. Leinz (Munich, 1980), pp. 310-21.

20. Kühn (1976, p. 16) mentions an earlier collection of inscriptions built up by Sigismund Masterlin (died 1489).

21. H.C. Ackermann, 'The Basle cabinets of art and curiosities in the sixteenth and seventeenth centuries', in The Origins of Museums, ed. O. Impey and A. MacGregor (Oxford, 1985), p. 64.

22. G. Heres, 'Die Anfänge der Berliner Antiken-Sammlung: zur Geschichte der Antikenkabinetts 1640-1830', Statliche Museen zu Berlin, Forschungen und Berichte 18 (1977), p. 97.

23. Since much of Friedrich Wilhelm's youth was spent in Kleve and he was educated at Leiden, he had considerable exposure to the forces of Dutch Humanism which may have conditioned his collecting activities. It is even possible that he first formed a collection while in Kleve (Rolf Bothe, 'Antike Sammelobjecte in Kleve und ihre Veröffentlichungen im 17. Jahrhundert', in Berlin und die Antike, ed. W. Arenhövel and C. Schreiber (Berlin, 1979), p. 298).

24. See Bothe 1979, pp. 293-8. An influential figure in Friedrich Wilhelm's orbit was Johan Maurits van NassauSiegen, Stadholder in Kleve under the Brandenburg electors from 1647: he was an avid collector and may have helped form the Elector's enthusiasms.

25 . Heres 1977, p. 95 . An inventory of 1649 lists 67 gems, 39 brooches, 23 statuettes, 31 bronze utensils and a miscellany of other items, most of which are thought to have originated in the Rheinland. A second inventory, compiled twentythree years later, shows that the collection had doubled in size in the meantime.

26. The lamp itself was a powerful metaphor for the soul, a concept perhaps bound up with the widely-held belief that they burned even underground: this assertion accompanied two such lamps in one of the most famous collections of its day, exhibited in the anatomy theatre at Leiden in Holland, while Robert Plot, mentioned above, devoted considerable energy towards resolving the supposed problem which they posed: see his 'Discourse concerning the sepulchral lamps of the ancients, shewing the possibility of their being made divers waies', Philosophical Transactions of the Royal Society 14
(1684), pp. 806-11.

27. See Sklenár 1983, p. 30, fig. 4.

28. Stemmermann drew attention to both the heathen connotations of the pyramidal top of this cabinet and to its sepulchral resonances, the latter reinforced by certain elements of the painted decoration. Hermann himself had explained: 'Denn weil es heydnische Reliquien seiyn, hab ich mir auch eine heydnische Pyramide machen lassen' (see Stemmermann 1934, pp. 91-2).

29. Sklenár 1983, p. 50.

30. Sklenár 1983, p. 53.

31. Sklenár 1983, p. 40.

32. Quoted in R. Jessup, Man of Many Talents. An informal biography of James Douglas 1753-1819 (London and Chichester, 1975), p. 32.

33. Klindt-Jensen 1975, p. 49.

34 . See most recently the essays by Jørgen Jensen and Jørn Street-Jensen in Christian Jïrgensen Thomsen 1788 - 29 December - 1988 (Aarbøger for Nordisk Oldkyndighed og Historie 1988) (Copenhagen, 1988), pp. 11-18 and 19-28. With the exposition of this theory, Jensen (p. 18) observes, 'archaeology ... could develop into a systematic study of the classification and chronological arrangement of monuments and artifacts'.

35. Thomsen's system was first published as Ledetraad til nordisk Oldkyndighed in 1836; it appeared in a German translation in the following year and in English the year after that. 36. See G. Schwantes, 'Vor hundert Jahren', in Festschrift zur Hundertjahrfeier des Museums vorgeschichtlicher Altertïmer in Kiel (Neumünster, 1936), pp. 1-11.

37. J.J.A. Worsaae, The Primeval Antiquities of Denmark ... translated and applied to the illustration of similar remains in England, trans. and ed. W.J. Thoms (London, 1849), pp. 149-50.

38. Worsaae 1849 , p. 1.

39. See K. Böhner, 'Das Römisch-Germanisch Zentralmuseum - eine vaterländische und gelehrte Gründung des 19

Jahrhunderts', Jahrbuch des Römisch-Germanischen

Zentralmuseums Mainz 25 (1978), pp. 1-48.

40. Sklenár 1983, p. 68 